\title{
Green Synthesis and Characterization of Carboxymethyl Cellulose Fabricated Silver-Based Nanocomposite for Various Therapeutic Applications [Retraction]
}

Asghar MA, Yousuf RI, Shoaib MH, et al. Int J Nanomedicine. 2021;16:5371-5393

At the request of the authors, the Editor and Publisher of International Journal of Nanomedicine wish to retract the published article. Concerns were raised regarding the alleged duplication of images in Figure 2 and Figure 9 with similar images in Figure 4 and Figure 9 from an article published by the same authors in the International Journal of Biological Macromolecules, Asghar et al, 2020 (https://doi.org/10.1016/j.ijbiomac.2020.05.197). Specifically,

- Figure 2C, panel AgNPs appears to have been duplicated with Figure 4A, panel AgNPs from Asghar et al, 2020.

- Figure 2D, panel CMC-AgNPs appears to have been duplicated with Figure 4B, panel CS-AgNPs, which has been flipped, from Asghar et al, 2020.

- Figure 9B, panel Streptococcus mutans appears to have been duplicated with Figure 7B, methicillin resistant Staphylococcus aureus from Asghar et al, 2020.

- Figure 9C, panel Staphylococcus epidermidis appears to have been duplicated with Figure 7A, vancomycin resistant Staphylococcus aureus from Asghar et al, 2020.

The authors explained the TEM images in question were provided by the first author, Muhammad Arif Asghar, and on subsequent review and investigation from this author, have confirmed these images were not satisfactory. However, all the authors accept joint responsibility for the integrity of the reported research and agree with the decision to retract the article.

Our decision-making was informed by our policy on publishing ethics and integrity and the COPE guidelines on retraction.

The retracted article will remain online to maintain the scholarly record, but it will be digitally watermarked on each page as "Retracted".

\section{Publish your work in this journal}

The International Journal of Nanomedicine is an international, peer-reviewed journal focusing on the application of nanotechnology in diagnostics, therapeutics, and drug delivery systems throughout the biomedical field. This journal is indexed on PubMed Central, MedLine, CAS, SciSearch ${ }^{\mathbb{B}}$, Current Contents ${ }^{\mathbb{B}} /$ Clinical Medicine, Journal Citation Reports/Science Edition, EMBase, Scopus and the Elsevier Bibliographic databases. The manuscript management system is completely online and includes a very quick and fair peer-review system, which is all easy to use. Visit http:// www.dovepress.com/testimonials.php to read real quotes from published authors. 